\title{
JENIS-JENIS IKAN DI PADANG LAMUN PANTAI TONGKAINA
}

\author{
(The Types of Fishes in Seagrass bed inTongkaina Waters)
}

Jerly D. Assa ${ }^{1 *}$, Billy Th Wagey ${ }^{1}$, Farnis B. Boneka ${ }^{1}$

1. Program Studi IImu Kelautan, Fakultas Perikanan dan IImu Kelautan, Universitas Sam Ratulangi, Manado

*e-mail :derlee_eyi@rocketmail.com

Seagrass beds have various roles in the life of fishes where, seagrass beds can be used as an area of nursery ground, as a place to find food (feeding ground), and as an area to search protection. Seagrass species itself can provide a direct food source for fish. Most of the inhabitants of seagrass fishes are juvenile whereas the adults would spend their lives in other types of habitats. The purposes of this research were to identify associated biota specially fishes who live in seagrass bed, and to describe their common characteristics of each spesies as well as to identify the species of seagrass that inhabit in this area. In this research, it was found that there were ten species of fishes on seagrass bed in Tongkaina waters. Those fishes are generally classified as the fish dwellers. Hence, they forage in the area of seagrass mostly for finding food. Furthere more, the most dominant seagrass species found in seagrass in Tongkaina waters are Enhalus acroides and Thalassia hemprichii.

\begin{abstract}
Keywords: Types of Fish, Seagrass, Tongkaina Waters.
Padang lamun memilki berbagai peranan dalam kehidupan ikan dimana padang lamun dapat dijadikan daerah asuhan (nursery ground), sebagai tempat mencari makan (feeding ground), dan daerah untuk mencari perlindungan. Untuk spesies lamunnya sendiri dapat merupakan makanan langsung bagi ikan. Peranan lamun adalah sebagai daerah asuhan, dimana sebagian besar ikan penghuni padang lamun adalah ikan-ikan juvenil apabila telah dewasa akan menghabiskan hidupnya pada tempat lain.Jenis ikan yang yang di dapat pada padang lamun pantai Tongkaian dengan menggunakan survey jelajah dan alat tangkap gil net yaitu 10 jenis ikan. 10 jenis ikan yang di dapat pada saat penelitian di padang lamun pantai tongkaiana adalah umumnya penghuni daerah padang lamun dan ada juga ikan yang hanya mencari makan di daerah padang lamun atau ikan penghuni terumbu karang.Jenis lamun yang paling dominan di padang lamun pantai Tongkaina yaitu 2 jenis lamun. Kedua jenis lamun tersebut adalah lamun Enhalus acroides dan Thalassia hemprichii.
\end{abstract}

Kata kunci:Jenis-jenis ikan, Lamun, Pantai Tongkaina.

\section{PENDAHULUAN}

Padang lamun merupakan bentangan tetumbuhan berbiji tunggal (monokotil) dari kelas Angiospermae. Lamun adalah tumbuhan air yang berbunga (spermatophyta) yang hidup dan tumbuh terbenam di lingkungan laut, berpembuluh, berdaun, berimpang, dan berakar. Hidup terbentang pada kedalaman 0,5-20 meter, kemudian terumbu karang. Lamun mempunyai akar rimpang, daun, bunga dan buah. Secara ekologis, lamun mempunyai beberapa fungsi penting. Lamun merupakan produktifitas primer di perairan dangkal diseluruh dunia dan merupakan sumber makanan penting bagi banyak organisme (Terrados, 2003).

Salah satu ekosistem yang cukup luas di lingkungan perairan laut dangkal adalah padang lamun. Disamping mempunyai produktivitas biologis yang tinggi dari padang lamun, kekayaan ikan juga terkonsentrasi di padang lamun. Padang lamun memiliki distribusi cukup luas pada daerah tropik, lingkungan inisalah satu tempat yang disukai sebagai tempat berlindung, ruang hidup dan tempat mencari makan bagi beranekaragam jenis biota termasuk ikan (Haeruman, 2000). 
Padang lamun memilki berbagai peranan dalam kehidupan ikan dimana padang lamun dapat dijadikan daerah asuhan (nursery ground), sebagai tempat mencari makan (feeding ground), dan daerah untuk mencari perlindungan. Untuk spesies lamunnya sendiri dapat merupakan makanan langsung bagi ikan (Bengen, 2001). Menurut Hutomo (1985) peranan lamun adalah sebagai daerah asuhan, dimana sebagian besar ikan penghuni padang lamun adalah ikan-ikan juvenil apabila telah dewasa akan menghabiskan hidupnya pada tempat lain.

Faktor makanan mempunyai peranan penting dalam pertumbuhan individu. Untuk merangsang pertumbuhan yang optimal, diperlukan jumlah atau mutu makanan yang tersedia dalam keadaan cukup serta sesuai dengan kondisi perairan. Menurut Effendie (1979) makanan dapat merupakan faktor yang menentukan bagi populasi, pertumbuhan dan kondisi ikan, sedangkan macam makanan setiap spesies ikan biasanya bergantung pada umur, tempat dan waktu.

Dari hasil penelitian yang telah dilakukan Nagelkerken et al. (2000) melaporkan bahwa beberapa spesies ikan menggunakan daerah lamun dan mangrove sebagai daerah asuhan tempat membesarkan juvenile (nursery ground). Kelimpahan dan kekayaan jenis (species richness) tertinggi ditemukan di daerah padang lamun dan daerah berlumpur yang sekelilingnya ditumbuhi oleh vegetasi mangrove. Tujuan dari penelitian ini yaitu: Untuk mengetahui jenis-jenis ikan serta lamun yang paling dominan di pantai Tongkaina.

\section{METODE PENELITIAN}

\section{Tempat dan waktu penelitian}

Tempat penelitian dilaksanakan di Perairan Tongkaina yang adalah salah satu kelurahan di kecamatan Bunaken, Ibu Kota Manado, Sulawesi
Utara, Indonesia. Sedangkan waktu penelitian dilakukan Selama 4 bulan (Agustus-Desember 2015) sejak penysunan rencana kerja penelitian sampai penulisan skripsi. Namun pengambialan data di lapangan dilakukan pada tanggal 17 \& 18 Oktober 2015. Letak geografis kelurahan Tongkaina sebelah utara berbatasan dengan laut Sulawesi, sebelah selatan berbatasan dengan kelurahan Pandu, sebelah timur berbatasan dengan kelurahan Meras dan sebelah barat berbatasan dengan Desa Tiwoho Kecamatan Wori Minahasa Utara.

\section{Metode Pengumpulan Data}

Pengumpulan data atau sampel ikan dilakukan dengan menggunakan alat tangkap "jaring insang" gill net berukuran $1.5 \mathrm{~m} \times 2500 \mathrm{~m}$, dengan mata jaring $1.5 \mathrm{~cm}$ yang ditanam langsung di daerah perairan laut Tongkaina khususnya di padang lamun. Sampel Ikan di ambil pada saat air mulai surut. Sampel kemudian dibawa ke laboratorium Biologi Kelautan, diawetkan, diambil data digital dan kemudian diidentifikasi. Hasil ini selanjutnya dijelaskan spesifikasi dan karakteristik ikan secara umum serta kondisi lingkungan di lapangan. Dalam pengumpulan data ini juga, sampel lamun diambil dan diidentifikasi agar dapat diketahui jenis lamun apa yang ada di daerah penelitian pantai Tongkaina.

\section{Metode analisis data}

Data yang diperoleh diolah serta dianalisis dengan bantuan buku identifikasi serta literatur yang ada untuk menentukan jenis ikan apa yang di dapat pada saat pengambilan sampel ikan, serta jenis lamun apa yang ada di daerah pantai Tongkaina.

HASIL DAN PEMBAHASAN

Jenis-Jenis Ikan Di Padang Lamun 
Berikut ini penjelasan atau deskripsi mengenai ikan-ikan yang didapat pada saat penelitian di daerah padang lamun pantai Tongkaina :

1. Jack Fish, Ikan Kwe, Bobara (Sulut).

Karakteristik ikan ini badan pipih, punggung lebih cembung dibanding perut (khas untuk genus Caranx), terdapat scute pada ekor sebagai perpanjangan dari gurat sisi, sirip punggung kedua dan sirip dubur memanjang sampai ekor, dua duri keras didepan sirip dubur (umum untuk famili Carangidae) dan noda hitam pada tutup insang (khusus untuk spesies Caranx papuensis, noda tersebut berwarna putih). Sirip dada panjang dan membentuk bulan sabit (falcate). Warna badan sangat bervariasi, tergantung spesies. Spesies Caranx ignobilis berwarna hitam sampai keperakan.Jenis Gnathanodon speciosus berwarna kuning dengan garis-garis vertikal berwarna hitam. Sedangkan Caranx melampygus berwarna abu kebiruan dengan totoltotol hitam pada punggungnya. Famili Carangidae terdiri dari 33 genus, tujuh genus termasuk dalam kategori ikan Kuwe, yaitu: Alectis, Alepes, Atropus, Atule, Carangoides, Caranx, Gnathanodon, Trachinotus dan Uraspis. Nama lokal yaitu Languan, Putihan, Pulas Keladi, Cupak, Jamah, Repoh, Tai Ayam.

Habitat ikan ini tergantung dari spesiesnya, habitat dari ikan Kuwe sangat beragam, dari Pantai sampai Laut lepas (Oseanik) dan dari yang bersifat pelagis sampai mendekati dasar (Demersal). Caranx dan Gnathanodon sangat khas sebagai penghuni terumbu karang (Reef Associated). Hampir semua ikan Kuwe mempunyai sifat bergerombol (schooling) dan bersifat carnivor. Makanan utamanya adalah ikan dan Makrofauna lainnya.

Perikanan komersial dari ikan Kuwe sebagian besar ditujukan bagi jenis ikan yang bergerombol dan berada di luar habitat karang (Laut lepas). Alat tangkap yang paling dominan adalah Purse Seine dan Gill Net (sebagian kecil). Untuk jenis ikan Kuwe yang terdapat di terumbu karang, alat tangkap paling dominan adalah Pancing dan jaring Muro Ami. Di Indonesia, produksi ikan Kuwe terutama dijual segar dan untuk pindang. Ukuran yang tertangkap sangat beragam, tergantung dari spesiesnya. Jenis perikanan ini sangat penting bagi nelayan untuk pasar lokal dan domestik. Jumlah yang tercatat ditemukan di Indonesia 36 jenis ikan.

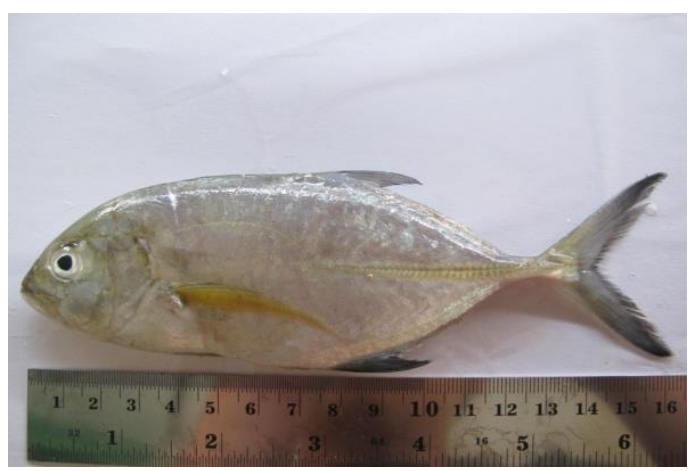

Gambar 1. Bobara.

2. Trigger Fish, Ikan Tato (Sulut), orange-lined triggerfish, Balistapus undulatus.

Ciri-ciri ikan jenis ini yaitu memiliki panjang max $30 \mathrm{~cm}$, badan hijau gelap kecoklatan dengan garis orange diagonal di badan dan muka. Memiliki spot hitam dipangkal ekor. Habitat ikan ini di daerah kaya karang di laguna dan terumbu karang. Jenis yang territorial, biasa meletakkan telur dalam lubang di daerah pasir atau rubble di daerah karang. Range kedalaman $1-50 \mathrm{~m}$. Distribusi ikan ini Indo-Pasifik, Laut merah, Afrika Selatan, Kepulawan Line, Marquesan dan Tuamoto, Jepang-GBR dan New Caledonia.Ikan ini merupakan ikan tipe pemakan Zoobenthos (Echinodermata, moluska, tunikata, sponge dan hydrozoa), ikan kecil dan alga bentik. 


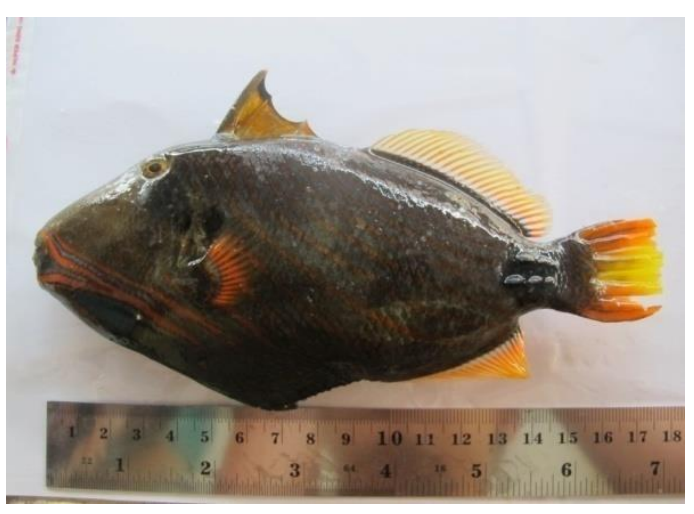

Gambar 2. Trigger Fish.

3. Chubs Fish, Ikan Tampalbor (Sulut). Ciri-ciri ikan ini memiki panjang maksimal $75 \mathrm{~cm}$, badan abu-abu keperakan kadang ada juga yang kuning dan putih albino. Garis yang terbentuk antara sirip ekor dan sirip anal lebih tegak dibandingkan $K$. vaigiensis. Habitat di daerah terbuka di lereng karango dan kadang di daerah dangkal dan karang berbatu. Range kedalaman 1-25 m. Distribusi ikan ini Indo-Pasifik, Merah, Timur Afrika, timur dan barat Australia, Kepulawan Lord Howe dan rapa dan Jepang. Ikan ini tipe pemakan Bentik alga, (Sargassum dan Turbinaria) bentik krustacea, cacing.

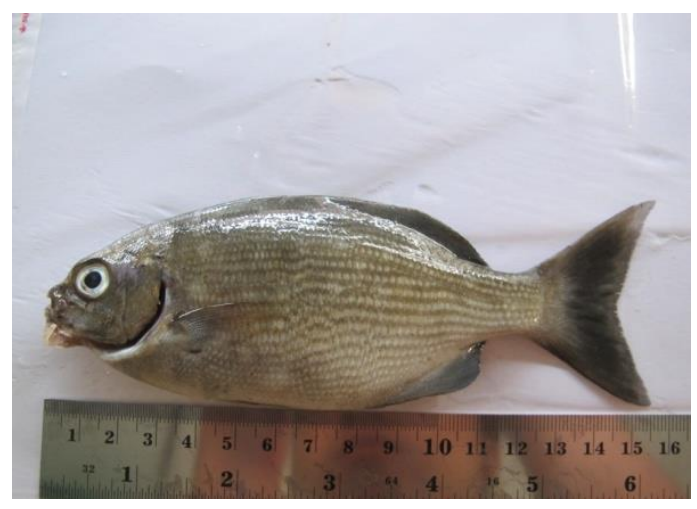

Gambar 3. Chubs Fish.

\section{Siganus Canliculatus (Park, 1797).} Ikan ini merupakan ikan family Siganidae disebut juga dengan nama ikan beronang. Seluruh tubuh dan siripnya terdapat bintik-bintik putih. Disamping jenis tersebut juga dijumpai $S$. guttatus dan $S$. vermiculatus.
Distribusi di Asia Tenggara, IndoPasifik.

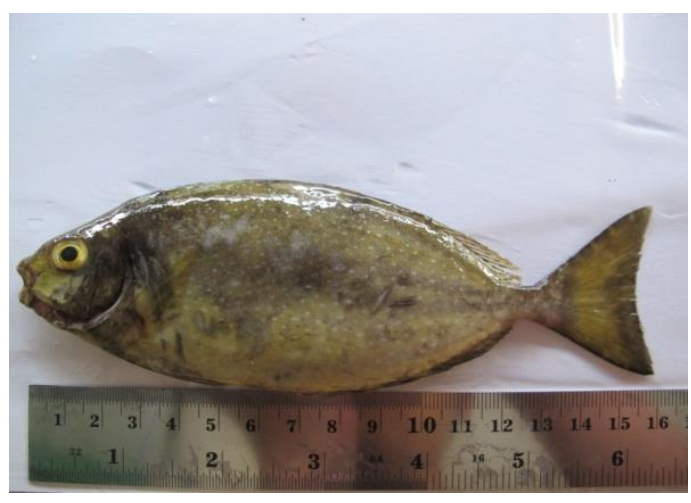

Gambar 4. Siganus Canaliculatus.

5. Ikan Biji Nangka.

Karakteristik badan ikan ini memanjang dan tertutup sisik sampai kepala, kecuali moncong sebelah depan. Mulut kecil dengan gigi yang lemah. Ciri khusus ikan ini adalah terdapat sepasang sungut pada rahang bawah dan garis membujur berwarna kuning pada sisi badan. Ciri ini dikombinasi dengan bentuk tubuh menjadi nama ikan ini terkenal dengan sebutan Biji Nangka. Secara keseluruhan ikan berwarna cerah. Genus yang sering ditemukan di Indonesia termasuk Mulloidichthy spp., Parupeneus spp., dan Upeneus spp. Nama lokal yaitu Kakunir, Kunir, Kuniran, Butir Nangka.

Habitatikan Biji Nangka termasuk jenis ikan demersal (hidup dekat dasar), sungutnya berfungsi sebagai alat peraba. Habitatnya adalah perairan pantai dengan tipe dasar lunak seperti lumpur. Beberapa jenis dari ikan ini juga ditemukan di bagian luar terumbu karang (Reef associated). Makanan utamanya adalah ikan kecil dan makrofauna lainnya (termasuk jenis predator).

Perikanan nelayan, terutama di wilayah Utara Jawa masih menjadikan ikan ini sebagai target, terutama dengan semakin berkurangnya hasil tangkapan Udang. Alat yang biasa digunakan adalah Dogol dan Payang, termasuk Lampara. Nelayan skala kecil 
juga sering menangkap ikan ini dengan alat Jaring Tarik. Ikan ini sebenarnya bisa mencapai ukuran $60 \mathrm{~cm}$, namun lebih sering tertangkap pada panjang sekitar $30 \mathrm{~cm}$. Jumlah spesies yang ditemukan di wilayah Pasifik Barat mencapai 29 jenis, semuanya tercatat ditemukan di Indonesia. Jumlah yang tercatat ditemukan di Indonesia mencapai 29 jenis.

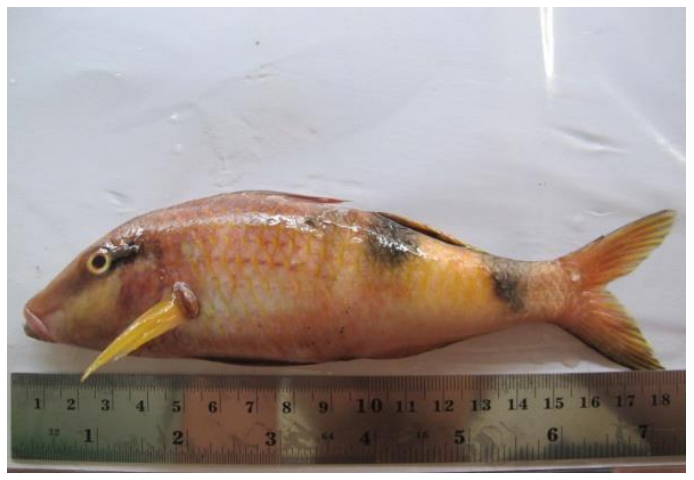

Gambar 5. Ikan biji nangka.

\section{Lethrinus Species.}

Ikan Lencam (Lethrinidae) adalah Ikan laut yang termasuk dalam famili Lethrinidae yang dikenal dengan sebutan ikan emperor. Ikan ini merupakan kelompok ikan target nelayan yang dimanfaatkan sebagai ikan konsumsi. Nama lain ikan ini diberbagai daerah di Indonesia adalah ikan asual, asuan, gotila, gopo, ketamba Lencam, mata hari, ramin dan sikuda.

Ordo Percomorphi, Famili Lethrinidae, Genus Lethrinus memiliki badan memanjang, agak lonjong, dan gepeng. Moncong agak meruncing. Memiliki sisik ctenoid dan memiliki operculum bersisik. Sisik transversal diatas garis rusuk berjumlah 56,sedang dibawah garis rusuk berjumlah 14-15. Jari-jari keras sirip punggung terdapat 10 dan 9 sirip punggung lemah. Sirip dubur berjari-jari keras 3 dan 8 berjari-jari lemah. Ikan ini termasuk ikan buas, makanannya umumnya crustacea, cacing dan ikanikan kecil. Hidup di perairan pantai dan dasar pasir. Dapat mencapai panjang
$40 \mathrm{~cm}$ dan umumnya $25-35 \mathrm{~cm}$. Warna bagian atas kehijauan dan agak kepucatan bagian bawah. Sisik-sisik pada bagian atas badan di tengahtengahnya berwarna putih seakan-akan membentuk totol-totol. Sirip-sirip berwarna kuning ungu kemerahan.

$$
\text { Lencam merah (Lethrinus }
$$

obsoletus) hidup di daerah pantai, perairan karang, dapat mencapai panjang $60 \mathrm{~cm}$, umumnya $35-50 \mathrm{~cm}$. Termasuk ikan demersal, ikan buas, makanannya ikan-ikan kecil, krustasea, dan cacing. Penangkapan dengan pancing, bubu, jaring insang, dan trawl. Dipasarkan dalam bentuk segar, asinkering. Daerah penyebarannya meliputi perairan pantai dan karang diseluruh Indonesia serta perairan Indo-Pasifik (Wikipedia, 2013).

Ikan

lecam Lethrinus spp merupakan ikan demersal kecil yang banyak tersebar di seluruh Indonesia. Ikan lecam Lethrinus spp merupakan ikan laut komoditas penting. Ikan lecam dapat diolah dan digunakan sebagai ikan asin, ikan kering, baso ikan, tempura ikan, dan lain-lain. Pemanfaatan ikan lecam sebagai olahan makanan di Indonesia telah mencapai tingkat ekspor. Tangkapan ikan Lecam di Indonesia terdapat hampir di seluruh pelabuhan perikanan di Indonesia. Sampai saat ini Ikan Lecam belum dinyatakan sebagai spesies yang teracam keberadaannya karena spesies ini tersebar hampir diperairan Hindia-Pasifik.

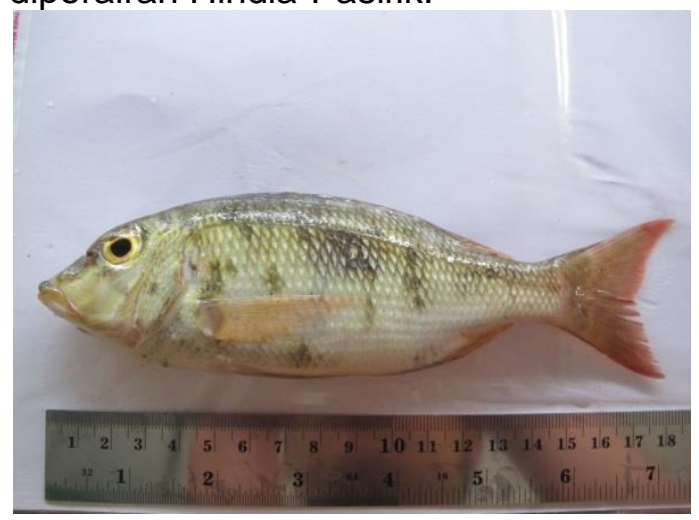

Gambar 6. Lethrinus species. 
7. Butana lorek, Convict surgeonfish, Acanthurus triostegus.

Ikan Butana lorek (A. triostegus) adalah ikan laut yang termasuk dalam family Acanthuridae. Ciri-ciri umum ikan jenis ini adalah memiliki panjang maximal $27 \mathrm{~cm}$, badan kuning krem dengan 6 garis vertical dibadan. Perubahan metamorphosis dari post larva-juvenil pada ukuran $3,2 \mathrm{~cm}$. Ikan jenis ini hidup di habitat daerah laguna dan karang, juvenile berada di daerah pasang surut, bentho pelagic, kadang mencari makan di daerah masukan air tawar dimana banyak alga. Distribusi ikan jenis ini yaitu di Indo-Pasifik, Arabian peninsula. Pasifik timur, Teluk California-Panama. Ikan jenis ini biasanya memakan Zoobenthos, bentik alga, dan fitoplankton.

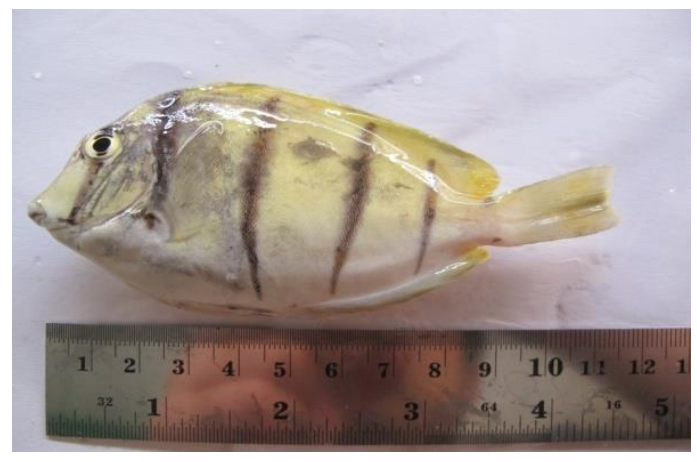

Gambar 7. Acanthurus triostegus.

\section{Novaculichthys taeniourus.}

Karakter diagnostik ikan ini Jarijari sirip punggung IX, 12 jari-jari sirip dubur III, 12 jari-jari sirip dada, 13 garis rusuk terputus, 19-20 sisik berpori di bagian depan atas dan 5-6 di bagian pangkal ekor. Badan oblong, pipih, tinggi badan 2.7-3.0 menurut panjang baku. Kepala kurang bersisik kecuali untuk 2 sisik di bagian atas tulang penutup insang dan baris sisik hampir tegak sisik-sisik kecil dibelakang mata. Sepasang gigi canine di bagian depan rahang. Dua jari-jari keras sirip punggung fleksibel, pada ikan-ikan muda sangat panjang.

Warna badan coklat tua
kehijauan dengan bercak putih
memanjang tegak di setiap sisik, kepala

abu-abu dengan garis coklat tua yang tidak teratur dari mata, 2 bercak hitam di bagian depan sirip punggung, pita/garis putih tegak yang lebar di dasar sirip ekor, bagian belakang sirip ekor hitam, sirip perut hitam. Ikan-ikan muda bercoreng dan berwarna coklat, kemerahan, atau hijau, dengan bercak putih. Ikan jenis ini dapat mencapai panjang $30 \mathrm{~cm}$. Ikan-ikan muda menyerupai rumput laut yang hanyut. Distribusi ikan ini di Indo-Pasifk.

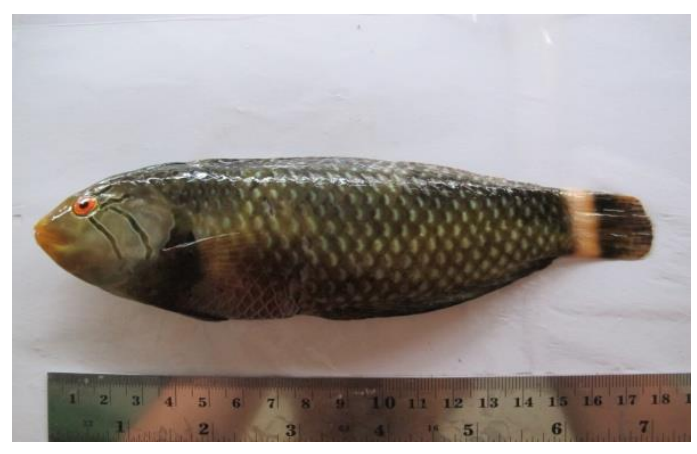

Gambar 8. Novaculichthys taeniourus.

9. Tripletail warasse, Cheilinus
trilobatus.
Ikan jenis ini termasuk dalam family Labridae. Ciri-ciri umum ikan ini memiliki panjang maksimal $45 \mathrm{~cm}$, hijau kemerahan tipis vertikal di badan, dua garis putih di pangkal ekor, garis tidak beraturan di kepala dan dada. Dewasa sirip ekor trilobe.Ikan jenis ini hidup di habitat laguana dan lereng karang bagi yang dewasa, juvenile daerah karang beralga dan di hydrozoa. Umumnya soliter.Distribusi ikan jenis ini di IndoPasifik, Kepulawan Timur Afrika. Tuamoto dan Australia, Kepulawan Ryukyu dan New Caledonia. Ikan jenis ini merupakan ikan jenis pemakan moluska, bentik krustacea, ikan kecil, dan echinodermata. 


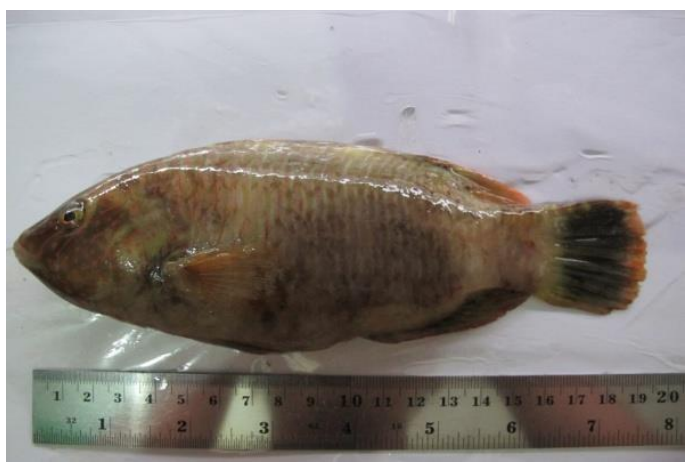

Gambar 9. Cheilinus trilobatus.

10. Baracuda fish, Ikan barracuda (Sphyraenidae).

Karakteristik badan ikan

memanjang seperti cerutu, mulut lebar dengan gigi taring (canine) yang kuat, rahang bawah lebih menonjol ke dapan (superior). Sirip ekor berbentuk emarginate dan, kedua ujung sirip ekor berwarna pucat. Pada tubuh bagian bawah terdapat noda-noda (blotch) berwarna hitam. Kepala diantara kedua mata datar atau sedikit cekung. Famili Sphyraenida hanya mempunyai satu genus dan 25 spesies. Jenis yang tertangkap di Indonesia diduga terdiri dari 7 spesies: Sphyraena barracuda, $S$. forsteri, $S$. helleri, $S$. jello, $S$. obtusata, $S$. putnamae dan $S$. qenie. Nama lokal ikan ini biasa disebut Kucul, Titil, Kacang-Kacang, Pengaluan, Tenak, Tenok, Kadalan, Leres, Tunel, Pengalasang, Senuk, Kacang Merah, Langsar, Tancak, Curut, Kacang Lopek. Habitat termasuk jenis ikan pelagis. Ikan muda berada di daerah bakau, estuari dan terumbu karang bagian dalam, ikan dewasa tersebar luas dari Pantai sampai laut lepas, bersifat Soliter namun bisa juga ditemukan dalam gerombolan kecil. Termasuk ikan carnivor, jenis makanannya dari ikan, Cephalopoda dan Udang.

Alat tangkap utama Pancing. Ikan ini bisa ditangkap pada seluruh perairan Indonesia dengan terumbu karang yang masih baik. Panjangnya dapat mencapai $160 \mathrm{~cm}$, namun ditangkap umumnya pada ukuran 40 cm. Jumlah yang tercatat ditemukan di Indonesia 7 jenis ikan.

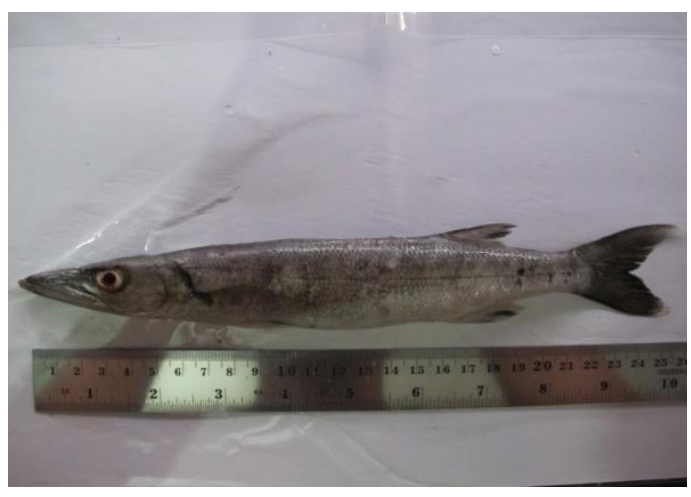

Gambar 10. Barracuda.

\section{Jenis-Jenis Lamun Yang Dominan}

Hamparan padang lamun di daerah pantai Tongkaina sangat luas berikut ini kami mengambil sampel lamun yang paling banyak atau dominan di padang lamun pantai Tongkaina dan kami menggambil dua spesies lamun yang paling dominan di pantai Tongkaina.

1. Enhalus acroides

Menurut den Hartog (1970), E. acoroides dapat diklasifikasikan sebagai berikut:

Kingdom : Plantae

Division : Anthophyta

Classis : Angiospermae

Sub Classis : Monocotyledonia

Ordo : Helobiae

Familia : Hydrocharitaceae

Genus :Enhalus

Species :Enhalus acoroides.

$E$. acroides merupakan tanaman yang tegak dengan daun sebanyak $2-5$ helai dan rimpang kasar serta akar-akar yang kuat. Helaian daun berbentuk seperti pita dengan panjang dapat mencapai $75 \mathrm{~cm}$ dan lebar $1,0-1,5 \mathrm{~cm}$. Rimpang tebal mencapai $1 \mathrm{~cm}$. Bunga jantan dan bunga betina masingmasing berasal dari tanaman yang berbeda. jantan umumnya berada pada bagian bawah tanaman dengan benang sari berukuran besar. Bunga betina mempunyai tangkai pendukung yang panjang. Benang sari ketika dilepaskan dari bunga jantan selalu 
mengapung di permukaan air kemudian tersebar mengikuti arah arus air laut dan selanjutnya tenggelam secara perlahan-lahan untuk membuahi bunga betina. Buah berbentuk seperti telur dan mempunyai 12 biji.

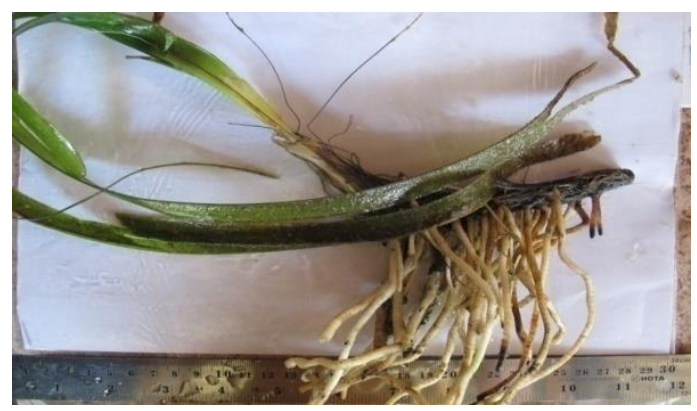

Gambar 11. E. acroides.

\section{Thalassia hwmprichii.}

Menurut den Hartog (1970), T. hemprichii dapat diklasifikasikan sebagai berikut :

Kingdom : Plantae

Division : Spermatophyta

Classis : Angiospermae

Sub Classis : Monocotyledonia

Ordo : Helobiae

Familia : Hydrocaritaceae

Sub family : Vallisnerioideae

Genus : Thalassia

Spesies : Thalassia hemprichii.

T. Hemprichii memiliki daun lurus sedikit melengkung, tepi daun tidak menonjol, panjang 5-20 cm, lebar mencapai $1 \mathrm{~cm}$. Seludang daun tampak nyata dan keras dengan panjang berkisar antara 3-6 cm. Rimpang keras, menjalar, ruas-ruas rimpang mempunyai seludang.

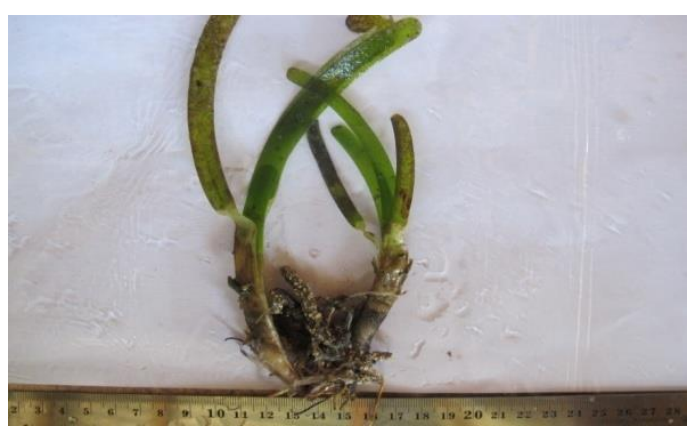

Gambar 12. T. hemprichii.

\section{KESIMPULAN}

Dari hasil penelitian yang dilakukan di pantai Tongkaina :

1. Jenis ikan yang yang di dapat pada padang lamun pantai Tongkaian dengan menggunakan survey jelajah dan alat tangkap gill net yaitu 10 jenis ikan, sedangkan jumlah individu yang didapat adalah 20 individu. 10 jenis ikan yang di dapat pada saat penelitian di padang lamun pantai tongkaiana adalah umumnya penghuni daerah padang lamun dan ada juga ikan yang hanya mencari makan di daerah padang lamun atau ikan penghuni terumbu karang.

2. Jenis lamun yang paling dominan di padang lamun pantai Tongkaina yaitu 2 jenis lamun. Kedua jenis lamun tersebut adalah lamun $E$. acroides dan $T$. hemprichii.

3. Daerah padang lamun pantai Tongkaina memiliki keanekaragaman lamun serta ikan yang mendiami perairan pantai Tongkaina.

\section{DAFTAR PUSTAKA}

Bengen D.G. 2001. Ekologi dan Sumberdaya Pesisir dan Laut Serta Pengelolaannya Secara Terpadu dan Berkelanjutan. Prosiding Pengelolaan Wilayah Pesisir Terpadu. Bogor 23 Oktober - 3 November 2001. Pusat Kajian Sumberdaya Pesisir dan Lautan (PKSPBL)-IPB. Bogor.

Den Hartog, C. 1970. Seagrass of the World, North-Holland Publ.Co, Amesterdam.

Effendie, M.K. 1979. Metode Biologi Perikanan. Yayasan Dewi Sri, Bogor, $112 \mathrm{Hal}$.

Effendie, M.K. 1997. Biologi Perikanan. Yayasan Pustaka Nusatama, Yogyakarta, $163 \mathrm{Hal}$.

Haeruman. 2000. IImu Usaha Tani. Penebar Swadata, Jakarta. 
Hutomo, M. 1985. Telaah Ekologik Komunitas Ikan padang lamun (Seagrass, Antophyta) di perairan Teluk Banten. Disertasi Fakultas Pasca Sarjana IPB. Bogor.

Kikuchi, T. 1974. Japanese contribution on consumer ecology in eelgrass (Zostera marina L) beds, with special reference to trophic relationship and resources in inshore fisheries. Aquaculture 4 (2):161-167.

Kikuchi, T., J.M. peres 1977. Cosumer Ecology of Seagrass Beds, In $\mathrm{mc}$ and $\mathrm{C}$, Helferich (eds.) Seagrass Ecosystem, A scientific Perspective, Mar, Sci, Vol, 4 Marcel Inc, New York: $p$ 357.

Nikolsky, G.V. 1963. The Ecology of Fishes. Academy Press London, p 153.

Pereira, P.H.C., B.P Ferreira dan S.M. Rezende. 2010. Community structure of the inchtyofauna associated with seagrass beds (Halodule Wrightii) in Formoso River estuary - Pernambuco, Brazil. Anais da academia Brasileira de Ciencias (2010) 82(3): 617-628.

Terrados, J., C.M. Duarte. 2003. Seagrass Ecosystem, South east Asian.

Thayer, G., W.S.M. Adams dan M.W. La Croix 1975. Structural and Functional Aspects of a Recently Established Zostera Marina Community, In : I, e, Onin (ED.), Estuarine Research Vol, I, Academic Press, New York: $p 207$.

Thomlinson, P.B, 1974. Vegetative Morphology and Meristem Dependence the Foundation of Productivity in Seagrass, Aquaculture 4: 107-130.

Wagey, B.T. 2013. Variation in Chlorophyll $a$ and $b$ in the Seagrass in Central Visayas, Philippines.
International Journal of Ecology and Conservation. Vol 8. No 1.

Wagey, B.T, A.A. Bucol and V. Katuuk. 2015. The Moray Eel Fishery in the Seagrass Beds of Siquijor Island, Central Philippines, with Remarks on Two New Philippine Records of the GenusGymnothorax. IAMURE International Journal of Ecology and Conservation. Vol 13.No.1. 